\title{
E.M. Uhlenbeck (1913-2003) and the Royal Netherlands Institute of Southeast Asian and Caribbean Studies (KITLV)
}

Eugenius Marius Uhlenbeck (1913-2003) needs no introduction to readers of this journal. Bob, as many knew him, was editor of the Bijdragen tot de Taal-, Land-en Volkenkunde from 1949 until 1958. He took up this task after he obtained his PhD for his dissertation on the structure of the Javanese morpheme, ${ }^{1}$ and remained as editor until he was appointed chair in general linguistics at Leiden University, where he also held the chair in Javanese language and literature from 1950 until 1983. ${ }^{2}$ During his lifetime, he contributed fourteen articles to the journal. ${ }^{3}$ Many of these have become classics in their fields, particularly his studies of various aspects of Modern Javanese morphology ${ }^{4}$ and his interpretation of several Old Javanese texts. ${ }^{5}$ In addition, he also published eleven reviews in the Bijdragen. ${ }^{6}$ Among these, his article on Zoetmulder's study of language of the Adiparwa (1950) deserves special mention. ${ }^{7}$ In addition to his contributions to the Bijdragen, the Royal Netherlands Institute of Southeast Asian and Caribbean Studies (KITLV) published five important monographs written by him. ${ }^{8}$

This brings me to the focus of this paper: the relationship between Uhlenbeck and the KITLV. My sources include the abridged minutes of the meetings of the board of governors and the general assembly of the institute published in the Bijdragen between 1949 and 1955, and the annual reports published after 1955. ${ }^{9}$ The information gathered from the minutes and annual reports is supplemented by an interview conducted by Harry A. Poeze and Gerrit

1 Uhlenbeck 1949. For full references to the works of E.M. Uhlenbeck see Janse 2008.

2 For bio-bibliographical essays on E.M. Uhlenbeck, see Janse and Swiggers 1996; Willem F.H. Adelaar 2003; Janse 2004; Portielje 2004; Muysken 2005. For shorter notes, see Janse 1998a, 1998b; Kooij and Steinhauer 2004.

3 Uhlenbeck 1953b, 1953c, 1954a, 1955a, 1958c, 1961b, 1967d, 1975b, 1981f, 1983e, 1986c, 1989a, 1992e, 1997a.

4 Uhlenbeck 1953b, 1953c, 1954a, 1955a, especially the (revised) English versions in Uhlenbeck 1978 a.

5 Uhlenbeck 1958c, 1975b, 1989a.

6 Uhlenbeck 1951a, 1951b, 1951c, 1952a, 1952b, 1960f, 1960g, 1960h, 1960i, 1969e, 1972b.

7 Uhlenbeck 1952b; see also Uhlenbeck 1981f, 1992e for critical comments on American studies of Old Javanese.

8 Uhlenbeck 1960a, 1960b, 1958a, 1964a, 1978a.

9 More on the history of KITLV in Baaij et al. 2001; Kuitenbrouwer 2001; Honderdvijftig jaar KITLV 2001. 
Knaap on 19 September 1994, in which Uhlenbeck provided invaluable inside information about his relationship with the KITLV. ${ }^{10}$ The interview was transcribed by Tom van den Berge, which he kindly made available to me for the purpose of preparing this paper. I will briefly sketch the important role played by Uhlenbeck in the transformation of the Bijdragen and the Verhandelingen, in the foundation of the Translation Series and the Bibliographical Series, and the relocation of the KITLV from The Hague to Leiden.

Having graduated in Indology (Indonesian studies) from Leiden University and in Indonesian Law from Utrecht University in $1939,{ }^{11}$ Uhlenbeck went to the Dutch East Indies (Indonesia) to take up a position as the government linguist for Javanese language and literature at the Bureau for Popular Literature (Balai Pustaka) in Batavia (Jakarta). He held this post from 1939 until 1942, when he was imprisoned by the Japanese. ${ }^{12}$ After the war, Uhlenbeck returned to Jakarta to lecture in general and Indonesian Linguistics at the University of Indonesia, a position he held from 1946 until 1948. In 1949 he obtained his PhD cum laude under the supervision of C.C. Berg (1900-1990). In the same year Berg took up the newly created chair in Austronesian Linguistics at Leiden University, leaving his chair in Javanese Language and Literature to Uhlenbeck. Uhlenbeck was officially appointed at the end of 1949 and was sworn in on 5 January 1950.

In 1949 Uhlenbeck became a member of the KITLV. The previous year, on the initiative of G.W.J. Drewes (1899-1992), the board of governors of the institute decided to appoint an editorial board for the Bijdragen. ${ }^{13}$ The main reason for this initiative was the increasing cost of production of the journal. This was due to the fact that many articles were actually (re)written at the stage of the galley proofs by their authors, who were more often than not also members of the Board. ${ }^{14}$ One of the board members, J. Gonda (1905-1991), stated officially that the idea was 'to make something new of the journal'. ${ }^{15}$

10 Much of this information was known to me from the many informal conversations Bob and I had in our shared office in the National Library of the Netherlands (Koninklijke Bibliotheek) in The Hague when he was Secretary General of the Permanent International Committee of Linguists (1977-1992), in his house in Voorhout, and in mine in Ghent.

11 Uhlenbeck studied Javanese under C.C. Berg and Malay under Ph.S. van Ronkel; see Uhlenbeck's biographical notes (1991e) on the former and his review (1951b) of the festschrift in honour of the latter.

12 For a personal appreciation of the importance of Balai Pustaka with further references, see Uhlenbeck 1986c.

13 Bestuursvergadering 24 September 1949 (BKI 106-1, 1950, p. iv), Bestuursvergadering 15 October 1949 (BKI 106-1, 1950, p. vii). For a biographical note on Drewes, see Teeuw 1994.

14 An echoe of this problem can be found in the minutes of the meeting of the board of governors of 11 March 1950 (Bestuursvergadering 11 Maart 1950, BKI 106-3/4, 1950, p. xxvi), when a letter from the printer Smits dated 6 March 1950 concerning the huge amount of corrections in one particular galley proof was discussed.

15 ' $[\mathrm{H}]$ et oorspronkelijke idee om iets nieuws te maken van het Tijdschrift' (Bestuursvergadering 19 November 1949, BKI 106-1, 1950, p. xi). For biographical notes on Gonda, see Bodewitz 1991. 
However, it seemed that the board of governors was dissatisfied with both the quantity and the quality of the articles that were submitted for publication. ${ }^{16}$ At the meeting of the board on 19 November 1949 the names of four candidates for the new editorial board were presented: V.E. Korn (18921969), then vice-chairman of the board of governors, F.D.K. Bosch (1886-1967) and H.Th. Fischer (1901-1976), both members of the board of governors, and E.M. Uhlenbeck, at that time only an ordinary member of the KITLV. ${ }^{17}$ The fifth member of the editorial board had to be either Berg or Gonda, who were also members of the board of governors. Neither of them appeared to be interested in the job and it was eventually filled by F.W. Stapel (1879-1957), the chairperson of the board of governors. ${ }^{18}$ The official announcement of the composition of the editorial board was made during the meeting of the board of governors on 21 January 1950. Uhlenbeck, who now held the chair in Javanese Language and Literature at Leiden University, was announced as a member of the board and also elected as its secretary. ${ }^{19}$

Uhlenbeck was clearly the odd one out in this list, since he was the only person who was not at that time a member of the board of governors. ${ }^{20}$ The reason for his inclusion was his invaluable experience as a publisher at Balai Pustaka and his expertise in Javanese language and literature. When the board of governors met on 15 April 1950, Uhlenbeck was invited to explain how the editorial board proposed to improve the quality of the Bijdragen. ${ }^{21}$ Although the proposals were presented as being the work of the entire editorial board, it is clear that it was Uhlenbeck who was driving the transformation of the journal. The main proposal was to publish shorter and 'more readable' academic articles in the Bijdragen, while the more technical treatises would be published in the Verhandelingen. ${ }^{22}$ The idea was to make the Bijdragen more attractive. By way of incentive, the editorial board suggested remunerating authors who contributed to the Bijdragen..$^{23}$ The editorial board also propos-

16 This can be gathered from the request by the chair of the board of governors, F.W. Stapel, to submit copy for the Bijdragen (Bestuursvergadering 17 December 1949, BKI 106-1, 1950, p. xv).

17 Bestuursvergadering 19 November 1949 (BKI 106-1, 1950, p. xi). For biographical notes on Korn, see Prins 1973; on Bosch, see Pott 1972.

18 Drewes had made it clear from the very beginning that he was not a candidate for membership of the editorial board (BKI 106-1, 1950, pp. iv, vii, xi, xv). For biographical notes on Stapel, see Vogel 1989.

19 Bestuursvergadering 21 Januari 1950 (BKI 106-3/4, 1950, p. xvii).

20 Uhlenbeck was the second of three candidates nominated to fill the vacancy of Stapel in the board of governors (Bestuursvergadering 19 November 1949, BKI 106-1, 1950, p. xi), but the general assembly unanimously elected the first candidate, R.A.J. van Lier (1914-1987). For biographical notes on the latter, see Gomperts 1988.

21 Bestuursvergadering 15 April 1950 (BKI 106-3/4, 1950, p. xxvi).

22 Examples of such more technical treatises are Uhlenbeck 1960a, 1960b.

23 It should be noted that the absence of a fee for contributors to the Bijdragen had been one of the main reasons why Drewes had refused to become a member of the editorial board (see BKI 106-1, 1950, pp. iv, vii, xi, xv). 
ed the publication of English abstracts of articles written in Dutch, and the inclusion of book reviews, bibliographies and a discussion section. The first reviews appeared in the first issue of volume 107, published in 1951, the year in which the KITLV celebrated its first centenary. ${ }^{24}$ The special jubilee issue was the first to appear with the new cover, to give it a 'more modern' appearance. The idea to provide English abstracts was never really implemented, but gradually more and more English articles appeared in the journal. In the new millennium, English seems to have been adopted as the lingua franca of the Bijdragen, at least as far as its articles are concerned. ${ }^{25}$ Since 1998 the journal also has a parallel English title: Journal of the Humanities and Social Sciences of Southeast Asia and Oceania. ${ }^{26}$

The suggestion to publish bibliographies in the Bijdragen was never implemented. Instead, Uhlenbeck helped to launch two new book series, in addition to the Verhandelingen. The first was the Bibliographical Series, the first volume of which dealt with the languages of Sumatra (Voorhoeve 1955). The idea was to present critical surveys of studies written mainly in Dutch, on the languages, literatures and cultures of Southeast Asia and Oceania. The specific purpose was to provide reliable guides in the various fields, including making them available to non-native speakers of Dutch. ${ }^{27}$ Uhlenbeck himself contributed two volumes to the series: one was a volume co-authored with A.A. Cense on the languages of Borneo (Uhlenbeck 1958a), the other (Uhlenbeck 1964a) was on the languages of Java and Madura. ${ }^{28}$ The Bibliographical Series has published twenty-three surveys in total. The second series was the Translation Series, which had a similar purpose, namely to make available to a wider international audience important studies, originally written in Dutch, on a wide range of themes in the humanities and social sciences of Southeast Asia and the Caribbean. The series currently counts twenty-eight titles, including Pigeaud's monumental five-volume Java in the fourteenth century (1960-63), Teeuw's two-volume Modern Indonesian literature (1967-1979) and Uhlenbeck's collected, revised and translated Studies in Javanese morphology (1978a).

In 1955 the Bijdragen published a short report on the publications of the institute in the period $1945-1955 .{ }^{29}$ Officially it was published by the editorial board, but it was actually written by Uhlenbeck himself. It gives us a

24 More on the first centenary of KITLV in Korn 1951; Jubileum-nummer 1951.

25 Uhlenbeck himself continued to contribute Dutch articles to the journal and it was not until the 1980s that his first English article appeared in the Bijdragen (Uhlenbeck 1981f, 1989a, 1992e).

26 The Caribbean is not mentioned in the English title, although it figures prominently in the English name of KITLV.

27 In actual practice, the vast majority of the volumes published in the Bibliographical Series deal almost exclusively with the languages, literatures and cultures of Indonesia.

28 In the interview (in 1994) conducted by Poeze and Knaap, Uhlenbeck says he was preparing a second edition of the volume on the languages of Java and Madura, but this was never published.

29 De publicaties van het Instituut in de periode 1945-1955 (BKI 112-1, 1956, pp. 91-3). 
much clearer picture of the problems faced by the Bijdragen at the end of the 1940s. The journal, Uhlenbeck wrote, had become 'a kind of archive' in which lengthy studies were often published. Readability, variation, topicality and presentation were clearly no priorities in those days. ${ }^{30}$ The appointment of the editorial board had led to a significant increase in the activities of the KITLV. The Bijdragen were now published on a quarterly basis, the Verhandelingen counted eighteen volumes at the end of 1955 as opposed to a mere four in 1946, and two new series had been launched. In the period 1951 to 1955, the institute produced twenty-four publications (excluding the Bijdragen) as opposed to just six in the preceding five years. The main reason for this was the fact that the institute received substantial support from the Dutch Organization for Scientific Research (NWO). The conclusion of the report is worth quoting in full, as it brings us to the lesser known aspects of Uhlenbeck's relationship with the KITLV:

The importance of the KITLV as the only institution that has regularly and continuously published on a large-scale basis in the humanities and social sciences of Southeast Asia is now also officially recognized with the grant of a government subsidy in 1955. Even if this government subsidy does not allow the development of all the activities the institute has in mind, it nevertheless provides a reasonable foundation. ${ }^{31}$

To understand the implications of this statement, we have to go back in time a few years. In 1949, the board of governors was facing a budget deficit of 15,000 Dutch guilders. ${ }^{32}$ Berg had succeeded in securing a subsidy of 7,000 guilders in 1949 from the $\mathrm{NWO}_{1}^{33}$ but the money was not made available until the summer of $1950 .{ }^{34}$ In the following year, however, no subsidy was granted, ${ }^{35}$ although the NWO did support the publication of volumes seven and eight of the Coen edition (Coolhaas 1952-53), which in effect amounted to an annual subsidy that was even more substantial than the block grant received in $1949 .{ }^{36}$ In the same year (1951), a first attempt was made to secure a government subsidy, but this was unsuccessful. ${ }^{37}$ In 1952 Uhlenbeck was elected an ordinary member

30 'Aan leesbaarheid, aan een afwisselende inhoud, aan een zekere wetenschappelijke actualiteit was men niet zo zeer gewoon aandacht te schenken; ook het uiterlijk van het tijdschrift genoot geen bijzondere verzorging' (BKI 112-1, 1956, p. 91).

31 'Sinds 1955 wordt de betekenis van het Instituut als vrijwel enige instelling, die regelmatig en op grote schaal over de taal-, land- en volkenkunde van Zuid-Oost Azië is blijven publiceren, ook officieel erkend door de toekenning van een rijkssubsidie. Al maakt deze rijkssteun nog geenszins mogelijk die ontplooiing van activiteit, die het Instituut voor ogen staat, zij geeft in ieder geval aan zijn arbeid een redelijke basis.' (BKI 112-1, 1956, p. 93).

32 Bestuursvergadering 19 November 1949 (BKI 106-1, 1950, p. x).

33 Jaarverslag 1949 (BKI 106-3/4, 1950, p. xxiii).

34 Bestuursvergadering 21 October 1950 (BKI 107-1, 1951, p. 101).

35 Jaarverslag 1951 (BKI 108-4, 1952, p. 413).

36 Jaarverslag 1952 (BKI 109-4, 1953, p. 389) and Jaarverslag 1953 (BKI 110-4, 1954, p. 394).

37 Jaarverslag 1951 (BKI 108-4, 1952, p. 413). 
of the board of governors. ${ }^{38}$ Taking advantage of his talents as a 'statesman', as Grace (1998:78) referred to him, Uhlenbeck was able to secure the government subsidy the board of governors had been trying in vain to negotiate. The Dutch Ministry of Education, Arts and Sciences agreed to reserve a subsidy of 25,000 guilders for the KITLV from their budget for 1955, a substantial amount of money, which would be used to promote English-language articles in the Bijdragen and to launch the Bibliographical and Translation Series. ${ }^{39}$ In 1958 the government subsidy was raised to 35,000 guilders, again through the agency of Uhlenbeck. ${ }^{40}$ The ministry also granted a once-only subsidy of 6,000 guilders in 1953 to cover the budget deficit. ${ }^{41}$ In addition, the ministry supported Anceaux's research of the languages of New Guinea for a period of three years with an annual subsidy of 16,500 guilders. This subsidy was also matched by an annual subsidy from the NWO of 20,000 guilders. ${ }^{42}$ In the last published annual report of the institute (1989), the government subsidy had reached the phenomenal amount of 3,340,500 guilders. ${ }^{43}$

Meanwhile Uhlenbeck had conceived a very ambitious and highly controversial plan: the relocation of the institute from The Hague to Leiden. Before the independence of Indonesia it made sense for the institute to be situated in The Hague, as that was the centre for those who returned to the Netherlands after a career in Indonesia. After the independence of Indonesia, this was no longer the case. More importantly, and this was the main impetus for Uhlenbeck's initiative, the academic centre for Indonesian studies was not The Hague, but Leiden where the university was based, with chairs in Indonesian, Javanese and comparative Austronesian studies. Uhlenbeck had recently been appointed to several key positions in the administration of Leiden University. In 1954 he became secretary of the Faculty of Letters. As part of his task he drew up a long-range plan for the faculty which involved the foundation of three research centres: one for study of the Near East, another for Indonesian studies, and a third for Western studies. The foundation of a new centre for Indonesian studies at the Binnenvestgracht opened up the possibility of integrating the KITLV with the university. To achieve this, however, Uhlenbeck had to convince the board of governors of the institute as well as the board of governors of the university.

In 1954 he was in a particularly influential position at the university as he had been elected a member of a task force to develop a plan to reorganize its form of government. Uhlenbeck proposed to establish a presidium of which

38 Jaarverslag 1952 (BKI 109-4, 1953, p. 387).

39 Jaarverslag 1954 (BKI 111-2, 1955, p. 218) and Jaarverslag 1955 (BKI 112-3, 1956, p. 329).

40 Jaarverslag 1958 (BKI 115-1, 1959, pp. 109, 112).

41 Jaarverslag 1954 (BKI 111-2, 1955, p. 223).

42 Jaarverslag 1955 (BKI 112-3, 1956, p. 330) and Jaarverslag 1956 (BKI 113-1, 1957, p. 110). For biographical notes on Anceaux, see K. Alexander Adelaar 1989.

43 Jaarverslag 1989 (BKI 146-2/3, 1990, p. 398). 
the rector and the deans of all the faculties would be members. On its establishment Uhlenbeck became the first chairperson, holding this position from 1957 to 1961 . Because of his central role in the reorganization of the university, Uhlenbeck was able to convince the board of governors of the university to offer the board of governors of the KITLV accommodation for the institute in the university's planned complex at the Binnenvestgracht. The official letter dated 29 October 1956 was actually drafted by Uhlenbeck and discussed by the board of governors of the KITLV, though by the end of the year no decision had been taken. ${ }^{44}$ At the time Uhlenbeck was not an official member of the Board of the KITLV because of the rotation system, although he was reelected in 1957.45

The offer of the Leiden University board of governors was again discussed during three extremely well-attended meetings of the general assembly of the KITLV in $1958 .{ }^{46}$ There were heated debates on the pros and cons of shifting to Leiden. Many older members in particular did not want the institute to move. For some of them it was for personal reasons. One of the main reasons for not relocating was that The Hague was in a way neutral territory, neither in Utrecht nor in Leiden, where the two major research centres for Indonesian studies were based. At the same meeting, however, it was made clear that no financial support would be forthcoming from the municipality of The Hague. This fact made the Leiden proposal an offer the KITLV simply could not refuse. The final decision was taken at the meeting of the general assembly on 21 March 1959. Article 1 of the Regulations was amended as follows:

The Royal Institute is currently in The Hague. As soon as the proposed facilities are available in Leiden the institute will be transferred there. The institute will be housed in a new Center for Oriental Studies founded by the state university at Leiden. Care will also be taken to ensure the collections of the institution are properly set up there. These measures need to be efficiently implemented to safeguard the autonomy of the institute. After the physical relocation of the institute to Leiden, the statutory seat of the institute will also be transferred to Leiden. ${ }^{47}$

The relocation of the KITLV from The Hague to Leiden was planned for sometime between 1965 and 1970, as the building plans for the new university com-

44 Jaarverslag 1956 (BKI 113-1, 1957, p. 110).

45 Jaarverslag 1957 (BKI 114-3, 1958, p. 339).

46 Jaarverslag 1958 (BKI 115-1, 1959, p. 108).

47 'Het Koninklijk Instituut is gevestigd te 's-Gravenhage. Zodra in een door de Rijksuniversiteit te Leiden gesticht nieuw centrum voor oosterse studien de gelegenheid aanwezig is voor de huisvesting van het Instituut, met inbegrip van een doelmatige opstelling van zijn verzamelingen, en daarbij het behoud van de zelfstandigheid van het Instituut is gewaarborgd, zal de huisvesting van het Instituut naar Leiden worden overgebracht; door deze overbrenging zal tevens de statutaire zetel van het Instituut naar Leiden zijn verplaatst.' (BKI 116-2, 1960, p. 295). 
plex in Leiden had to be finalized. ${ }^{48}$ Collaboration with Leiden University Library commenced at the end of the 1950s; new KITLV acquisitions were catalogued by the library and recorded in both catalogues. ${ }^{49}$ In the crucial 1960s, Uhlenbeck took up a more prominent position in the board of governors of the KITLV. In 1962, he was elected chairperson, a position he held until 1965, when he left for the United States to become visiting professor at the University of California at San Diego and subsequently a visiting fellow at the Center for Advanced Study in Behavioral Sciences at Stanford, California. ${ }^{50}$ The annual report for 1964 stated that the relocation plans had reached a new stage: the board of governors of Leiden University offered the institute accommodation in a new building on the Stationsplein, which was expected to be completed by the end of 1966 . The offer was accepted at the extraordinary general meeting of 16 October $1964 .^{51}$ The actual removal started in September 1966 and was completed by December of the same year, when the first visitors were welcomed in the new premises. ${ }^{52}$ The official reopening of the institute took place on 17 March 1967, in the presence of many dignitaries. ${ }^{53}$ On this occasion, Uhlenbeck gave his well-known address on the prospect of Dutch Oriental studies, which was published in the Bijdragen (1967d).

The annual report for 1967 discusses in detail the many positive outcomes of the relocation..$^{54}$ The integration of the institute with the university brought about interaction and collaboration with other institutes, such as the institute for Cultural Anthropology and Non-Western Sociology, which was housed in the same building. In the same year, the activities for the advancement of Indonesian studies were greatly expanded. ${ }^{55}$ This led to the Ontwerpplan voor de Samenwerking Nederland-Indonesië op het gebied van de Indonesische Studies, the Development Plan for Dutch-Indonesian Cooperation in Indonesian Studies which was presented in 1972 to the ministries concerned. ${ }^{56}$ In 1974 the Dutch government made a block grant of 780,000 guilders to promote academic collaboration with Indonesia in the field of linguistic and literary studies, history, archeology, customary (adat) law, anthropology and other social sciences. ${ }^{57}$ The positive impact of the Dutch-Indonesian Cultural Agreement were discussed in detail in the annual report for $1975 .{ }^{58}$ 
In June 1975, the university informed the institute about its plans to build new accommodation for the University Library and the Faculty of Letters at the Witte Singel and the Doelenterrein. ${ }^{59}$ The removal of the institute to the Reuvensplaats 2 in the Witte Singel/Doelen complex took place in $1983 .{ }^{60}$ By that time Uhlenbeck was no longer a member of the board of governors. He resigned in 1981 after having served on the board for thirty years. ${ }^{61}$ In the interview conducted in 1994 by Poeze and Knaap, Uhlenbeck muses on the history of the institute and the musings are worth quoting in full as they do justice to his invaluable achievements without false modesty:

Just the other day I was here at the Institute and they were all having drinks afterwards. God, you don't know what that calls up in my mind when I see that ... Not the drinks, mind you, I like having a drink myself every now and then ... but the fact that you work your way through a host of collaborators who are affiliated with the Institute. To me this is almost absurd ... I love it, don't get me wrong, really, but I say to myself: There used to be two old people to run the whole business ... It is unbelievable when you see all that; and all the more so, the presence of students in the reading room. The whole premises as they are now give me - to be sentimental about it - a warm feeling. I have achieved something in life after all; to have - it's damn true - put down that whole building over there. A bit thick of course, but can you imagine saying: "Isn't it wonderful ...

59 Jaarverslag 1975 (BKI 132-2/3, 1976, p. 387).

60 Jaarverslag 1983 (BKI 140-2/3, 1984, p. 382).

61 Jaarverslag 1981 (BKI 138-2/3, 1982, p. 393).

62 'Ik was hier pas op het Instituut en toen zaten ze allemaal een borreltje te drinken na afloop. God, je weet niet wat dat bij mij oproept als ik dat zie ... Niet dat borreltje, hoor, want dat drink ik zelf ook graag ... maar dat je je een weg baant door een hele schare van medewerkers die aan het Instituut verbonden zijn. Dat is voor mij absoluut idioot ... Ik vind het heerlijk, hoor, ik kan niet anders zeggen, maar ik denk bij mezelf: "Vroeger waren er twee oude mensen die daar het hele zakie..." Het is niet te geloven als je dat ziet. En a fortiori ook de aanwezigheid in de leeszaal van studenten. Dat hele pand zoals het daar is geeft mij - om het een sentimenteel element te geven - een warm gevoel. Ik heb in het leven toch iets bereikt dat ik - verdomd - dat hele gebouw daar toch heb neergezet. Iets overdreven natuurlijk. Kan je je voorstellen dat je zegt: "Dat is mooi..."' 
References

Adelaar, K. Alexander

1989 'In memoriam Johannes Cornelis Anceaux (4 juli 1920-6 augustus 1988)', Bijdragen tot de Taal-, Land- en Volkenkunde 145:1-7.

Adelaar, Willem F.H.

2003 'E.M. Uhlenbeck, 1913-2003', International Journal of American Linguistics 69-4:397-406.

Baaij, Reggie et al. (eds)

2001150 jaar KITLV. Alphen aan den Rijn: Werkgroep Indisch-Nederlandse Letterkunde.

Bodewitz, H.W.

1991 Jan Gonda, 14 April 1905-28 July 1991. Amsterdam: Royal Netherlands Academy of Arts and Sciences. [Gonda lecture, 1.]

Coolhaas, W.Ph.

1952-53 Jan Pietersz. Coen. Bescheiden omtrent zijn bedrijf in Indië. Deel VII. 's-GraGomperts, H.A. venhage: Nijhoff. Two vols. [KITLV.]

1988 'Rudolf Asueer Jacob van Lier, Paramaribo 24 augustus 1914-Wageningen 28 mei 1987', Jaarboek van de Maatschappij der Nederlandse Letterkunde 1988:180-95.

Grace, George W.

1998 'On the assumption that to learn a language is to construct a grammar', in: Mark Janse (ed.), Productivity and creativity; Studies in general and descriptive linguistics in honor of E.M. Uhlenbeck, pp. 69-81. Berlin: Mouton

Janse, Mark de Gruyter. [Trends in Linguistics, Studies and Monographs 116.]

1998a (ed.) Productivity and creativity; Studies in general and descriptive linguistics in honor of E.M. Uhlenbeck. Berlin: Mouton de Gruyter. [Trends in Linguistics, Studies and Monographs 116.]

$1998 b$ 'E.M. Uhlenbeck; A personal appreciation', in: Mark Janse (ed.), Productivity and creativity; Studies in general and descriptive linguistics in honor of E.M. Uhlenbeck, pp. ix-xii. Berlin: Mouton de Gruyter. [Trends in Linguistics, Studies and Monographs 116.]

2004 'Eugenius Marius Uhlenbeck, 1913-2003', Oceanic Linguistics 43-1:24557.

2008 'The works of E.M. Uhlenbeck (1913-2003); An annotated bibliography', Bijdragen tot de Taal-, Land-en Volkenkunde 164:390-410.

Janse, Mark and Pierre Swiggers

1996 E.M. Uhlenbeck. Bio-bibliographical notice. Leuven: Centre internationale de Dialectologie générale. [Bio-bibliographies et exposés, N.S. 5.]

Kooij, Jan G. and Hein Steinhauer

2004

'E.M. Uhlenbeck, 1913-2003', Lingua 114-2:93-4.

Korn, V.E.

1951

'Verslag der herdenking van het 100-jarig bestaan van het Koninklijk Instituut voor Taal-, Land- en Volkenkunde te 's-Gravenhage', Bijdragen tot de Taal-, Land-en Volkenkunde 107:305-16. 
Kuitenbrouwer, Maarten

2001 Tussen oriëntalisme en wetenschap; Het Koninklijk Instituut voor Taal-, Landen Volkenkunde in historisch verband, 1851-2001. Leiden: KITLV Press.

Muysken, Pieter C.

2005 'E.M. Uhlenbeck', Koninklijke Nederlandse Academie van Wetenschappen, Levensberichten en herdenkingen (2005):118-23.

Pigeaud, Th.G.Th.

1960-63 Java in the 14th century; A study in cultural history. The Nāgara-Kĕrtāgama by Rakawi, prapañca of Majapahit, 1365 A.D. The Hague: Nijhoff. Five vols.

Portielje, Cecile [KITLV, Translation Series 4.]

2004

'Professor E.M. Uhlenbeck, taalkundige (1913-2003)', Voortgang 22:20534.

Pott, P.H.

1972

'Frederik David Kan Bosch, Potchefstroom 17 juni 1887-Leiden 20 juli 1967', Jaarboek van de Maatschappij der Nederlandse Letterkunde (1972):10513.

Prins, J.

1973

'Victor Emanuel Korn, 's-Gravenhage 1 juli 1892 - 's-Gravenhage 25 juni 1969', Jaarboek van de Maatschappij der Nederlandse Letterkunde (1973):1608.

Teeuw, A.

1967-79 Modern Indonesian literature. The Hague: Nijhoff. Two vols. [KITLV, Translation Series 10.]

1994 'In memoriam G.W.J. Drewes, 28 November 1899-7 June 1992', Bijdragen tot de Taal-, Land-en Volkenkunde 150:27-49.

Vogel, J.

1989 'Stapel, Frederik Willem (1879-1957)', Biografisch woordenboek van Nederland. http://www.inghist.nl/Onderzoek/Projecten/BWN/lemmata/bwn3/

Voorhoeve, P. stapel.

$1955 \quad$ Critical survey of studies on the languages of Sumatra. 's-Gravenhage: Nijhoff. [KITLV, Translation Series 1.]

Zoetmulder, P.J.

1950 De taal van het Adiparwa; Een grammaticale studie van het Oudjavaans. Bandung: Nix. [Lembaga Kebudajaan Indonesia/Koninklijk Bataviaasch Genootschap van Kunsten en Wetenschappen, Verhandelingen 79.] 